\title{
Assessing impacts on geese from mining activities in the Ramsar site Heden, East Greenland
}

\author{
Undersøgelse af påvirkning fra mineaktiviteter $i$ Ramsarområdet Heden $i$ \\ Østgrønland
}

\author{
CHRISTIAN M. GLAHDER, DAVID BOERTMANN \& JESPER MADSEN
}

\begin{abstract}
Due to planned mining activities inside a Ramsar site in Jameson Land, East Greenland, studies of Pink-footed Anser brachyrhynchus and Barnacle Branta leucopsis geese were performed in 2008. An aerial survey in Jameson Land showed a threefold increase in the moulting geese over the last 20 years to c. 19,000 Pink-footed geese and 16,500 Barnacle geese. About 25\% of the Pink-footed geese can be affected by the mining activities. About one third of the breeding Pink-footed geese in Jameson Land breed in the affected area. The possible effects of the mining activities were assessed in relation to three disturbance scenarios, expressed by distances of $1.5,5$ and $10 \mathrm{~km}$ from the activities. The worst case

scenario (10 km zone) could affect 4,900 moulting Pinkfooted and 530 moulting Barnacle geese and at least 30 successfully breeding pairs of Pink-footed geese. In the proposed Ramsar replacement area in Jameson Land, moulting geese numbered c. 3,000 Pink-feet and 4,700 Barnacles. A monitoring study and a study of yet another replacement area are proposed.

Christian M. Glahder, David Boertmann and Jesper Madsen, National Environmental Research Institute, Aarhus University, Department of Arctic Environment, P. O. Box 358, Frederiksborgvej 399, 4000 Roskilde, Denmark.E-mail:cmg@dmu.dk
\end{abstract}

\section{Introduction}

In 1988, the Ramsar site Heden in East Greenland (centre c. $71^{\circ} 00^{\prime} \mathrm{N} ; 24^{\circ} 00^{\prime} \mathrm{W}$ ) was designated primarily to protect internationally important populations of moulting Pink-footed geese Anser brachyrhynchus and Barnacle geese Branta leucopsis (Greenland Home Rule 1990, Egevang \& Boertmann 2001). The area held at that time $2 \%$ of the Iceland/Greenland flyway population of Pink-footed geese and 7\% of the total Greenland flyway population of Barnacle geese (Mosbech et al. 1989, Boertmann 1991). Of importance for the designation were also other breeding birds like Red-throated Diver Gavia stellata, Long-tailed Skua Stercorarius longicaudus and Arctic Skua Stercorarius parasiticus, Dunlin Calidris alpina, Turnstone Arenaria interpres, Red Phalarope Phalaropus fulicaria and Red-necked Phalarope Phalaropus lobatus, as well as uncommon breeding birds like Sabine's Gull Larus sabini and Whimbrel Numenius phaeopus (Boertmann 2007).

In 2008, the mining company Quadra Mining Ltd. was granted an exploitation license that cov- ered the Malmbjerget area situated about $75 \mathrm{~km}$ north of the Ramsar site Heden. The company plans to exploit a large molybdenum ore and develop the north western part of Heden (Cessford 2007, Quadra Mining Ltd. 2008). The planned activities inside the Ramsar site, around Gurreholm (Figure 1), include the construction of a port with a large container terminal, a gravel road from the port north along the east side of the Schuchert River and a 2,000 m long air strip. Large trucks will transport molybdenum concentrate in containers to the port from where ships during the open water period in July-October will sail the concentrate out of the area. About 100 flights per year with aircraft, ranging from smaller fixed wing aircraft, over medium sized jet planes to Hercules transport planes are planned to service the area. The Greenland SelfGovernment has claimed the mining project of "urgent national interests". The Ramsar Convention Secretariat is in dialogue with the Greenland SelfGovernment and has accepted that the project can proceed provided that the impact of the activities is monitored and that an appropriate replacement area is found in advance. 


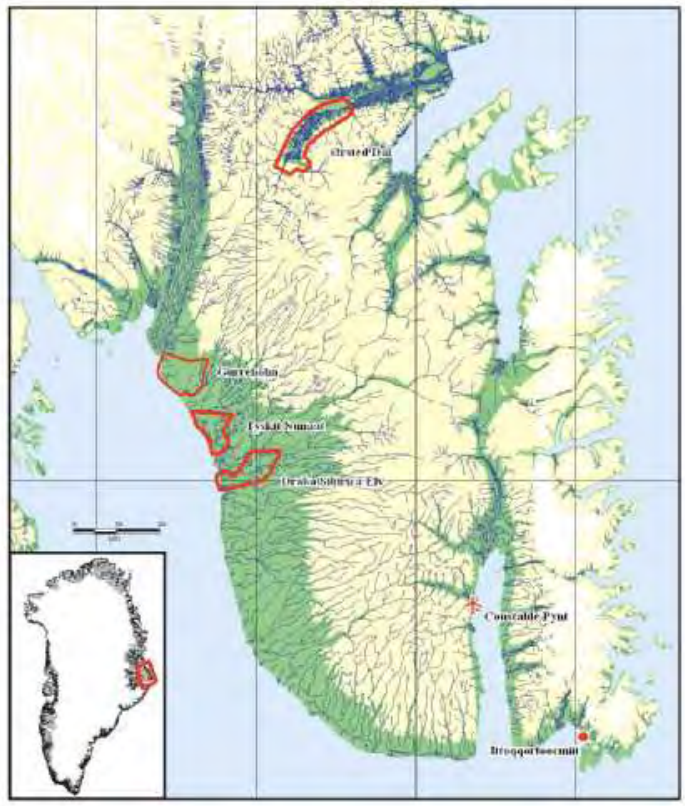

Figure 1. The four study areas in the northern part of Jameson Land, Greenland, where ground studies were conducted during 16 July-2 August 2008. The airport Constable Pynt and the settlement Ittoqqortoormiit are shown.

Kort over Jameson Land med angivelse af de fire undersøgelsesområder hvor der blev udført intensive undersøgelser $i$ perioden 16. juli til 2. august 2008. Lufthavnen Constable Pynt og bygden Ittoqqortoormiit er vist.

In July 2008 the National Environmental Research Institute (NERI), Denmark, conducted biological studies in the Ramsar site and other areas in Jameson Land. These studies were performed for the Bureau of Minerals and Petroleum, the Greenland Self-Government. On the basis of different disturbance scenarios the number of possibly impacted geese and other bird species were assessed and a larger area around the Ørsted Dal (Figure 1) was suggested as a replacement area (Glahder et al. 2008, 2010).

\section{The study area}

Jameson Land is situated in East Greenland around $71^{\circ} 15^{\prime} \mathrm{N} ; 23^{\circ} 30^{\prime} \mathrm{W}$. It is a lowland area compared to the generally rugged mountainous east coast of Greenland. The western and southern part is delimited by the World's largest fjord system Scoresby Sund while the northern and eastern part is fringed by high mountains and open sea. The western part is covered by tundra with a rather high proportion of wetland areas. To the east the area gradually raises to drier tundra and low mountains of about $1,000 \mathrm{~m}$ a.s.1. Jameson Land is intersected by many large rivers and relatively lush valleys.

The aerial survey covered most lowland areas of Jameson Land while ground studies were performed in the four areas of Gurreholm, Tyskit Nunaat, Draba Sibirica Elv and Ørsted Dal (Figure 1). Gurreholm is a wetland area with a high number of smaller and larger lakes, many marshes and smaller and larger rivers that drains the area. The higher ground in-between the wetland areas is dominated by dwarf scrub heath. Tyskit Nunaat is characterised by drier dwarf scrub heath with rather few rivers. There is only one large lake and relatively few smaller lakes and marshes. Draba Sibirica Elv is a lowland tundra area with a continuous dwarf scrub heath. The area is intersected by rivers and contains some lakes; marshes are found along rivers, streams and lakes and salt marshes along the coast of Scoresby Sund. Ørsted Dal is a 4-7 km wide, ushaped valley that runs east-west for about $50 \mathrm{~km}$. Many smaller and larger rivers run into the main river and the valley floor contains scattered ponds and lakes. The valley slopes are mostly covered by barren ground. Mossy fens are extensive along rivers and lakes while the river bed is covered by gravel and sand with only little vegetation.

\section{Methods}

During the period 16 July-2 August 2008 field work was performed by three different study groups from NERI. The one group conducted an aerial survey of moulting geese in the entire Jameson Land and the two other groups counted birds from the ground in four selected areas in Jameson Land (Figure 1).

The aerial goose survey was carried out on 17 and 18 July 2008, about one week before the first non-breeding geese attain their flying abilities. Weather conditions were optimal, with unlimited visibility, no winds and sky clear. The surveys were a replica of the surveys carried out in 1987, 1988 and 1989 (Mortensen et al. 1988, Mosbech et al. 1989, Mosbech \& Glahder 1990). Aircraft, pilot and one observer were the same as in the 1980s. The plane was a Partenavia P-68 Observer equipped with Plexiglas front and bubble windows. The flown routes were carried out as "total counts" (Laursen et al. 2008) and duplicated as far as possible from the routes in 1987-1989. Navigation 
was visual and aided by GPS. Survey speed and altitude was the same as in 1987-1989 i.e. 90 knots $(160 \mathrm{~km} /$ hour$)$ and 250 feet $(85 \mathrm{~m})$ above ground. The two observers were placed in the co-pilot seat (watching to the right) and the seat behind the pilot (watching to the left). Observations were recorded on tape-recorders with indication of time of the day (hour, minute, second) and subsequently written into a spreadsheet. The observation file was then by the time signal merged with the position file from the GPS resulting in positions of each single observation. The airport Constable Pynt (CNP) close to Ittoqqortoormiit/Scoresbysund was the base of the flights.

The ground surveys in the Gurreholm and Ørsted Dal areas were performed 17-25 July 2008 and in the reference areas Tyskit Nunaat and Draba Sibirica Elv during 25-31 July. The teams of two persons were moved to, from and between camp sites by a helicopter based at CNP. Each day, trips of 5-20 km were walked and during the study period $50-100 \mathrm{~km}$ was traversed in each study area. Routes formed radii from the camp sites to the areas' delimitations with a special focus on lakes and rivers. Thereby land areas of $48.6-68.9 \mathrm{~km}^{2}$ were covered. Binoculars (Leica \& Zeiss 10× magnification) and spotting scopes (Carl Zeiss Diascope 85 TFL 20-60×) were used for observations and GPS (Garmin Etrex and Trimble Recon $($ ) for positions. All birds and mammals were registered with species, number, age, behaviour and position. Positions were either GPS positions, calculated from observations plotted in the field on false colour infrared ASTER and Landsat satellite images from 15-17 July $2004(1: 25,000)$ or calculated from estimated distances and angles from the observer to the animals. Geese were separated in non-breeding moulting geese and breeding geese in family flocks which included young birds. For other bird species it was noted if birds were breeding or non-breeding; a breeding bird was defined as a bird connected to a nest with eggs or chicks, juvenile birds or a bird that performed territorial behaviour (e.g. lure or chase intruders, or sing). In mammals, fox dens and cubs were registered. All animal observations, camps, routes, observed lakes and observations points were plotted on false coloured satellite images $(1: 25,000)$ and if necessary verified by false coloured aerial photos (c. 1:22,000, 1980s).

\section{Results}

The total number of Pink-footed and Barnacle geese recorded in Jameson Land during the aerial survey was 19,068 and 16,603, respectively (Table 1, Figures 2 and 3). Almost all geese were moulting non-breeding birds. However, a total of 24 Pinkfooted and 45 Barnacle goslings were seen. Only 21 Pink-footed and 8 Barnacle geese were recorded flying.

The number of moulting Pink-footed geese and families counted in the four study areas either from the air or from the ground is shown in Table 2. Table 3 shows corresponding numbers for Barnacle geese. The average number of young per breeding pair of Pink-footed geese in the Gurreholm area was $2.80(n=76)$ and in Ørsted Dal $2.70(n=10)$. In Barnacle geese, the average number of young per pair in Ørsted Dal was $1.71(\mathrm{n}=17)$ and in Draba Sibirica Elv $3.83(n=6)$.

The number of other successfully breeding birds than geese in the four study areas is shown in Table 4. Breeding bird species included waders (Common Ringed Plover Charadrius hiaticula, Red Knot Calidris canutus, Sanderling Calidris alba, Dunlin, Ruddy Turnstone, Whimbrel and Red Phalarope), ducks (Common Eider Somateria mollissima, King Eider Somateria spectabilis and Long-tailed Duck Clangula hyemalis), skuas (Long-tailed and Arctic), Red-throated Diver, Rock Ptarmigan Lagopus muta, Arctic Tern Sterna paradisaea and Sabine's Gull. Non-breeding Sabine's Gulls were observed in relatively high numbers in Gurreholm (50-60) and Draba Sibirica Elv (20-30).

Table 1. Changes in the global flyway populations of Pink-footed Goose and Barnacle Goose and in the number moulting geese in Jameson Land during 1983-2008 (Mitchell 2008, Mitchell \& Walsh 2008, Mosbech \& Glahder 1990, the present study in 2008).

Andringer $i$ de globale flyway populationer af Kortncebbet Gås og Bramgås og $i$ antallet af faeldende goes $i$ Jameson Land i perioden 1983-2008.

\begin{tabular}{lrrrr}
\hline Goose species & \multicolumn{2}{c}{ Global flyway population } & \multicolumn{2}{c}{ Jameson Land population } \\
& 1990 & $2007 / 2008$ & $1983-1989$ & 2008 \\
\hline Pink-footed & 190,000 & 290,000 & 6,243 & 19,068 \\
Barnacle & 35,000 & 70,500 & 6,071 & 16,603 \\
\hline
\end{tabular}




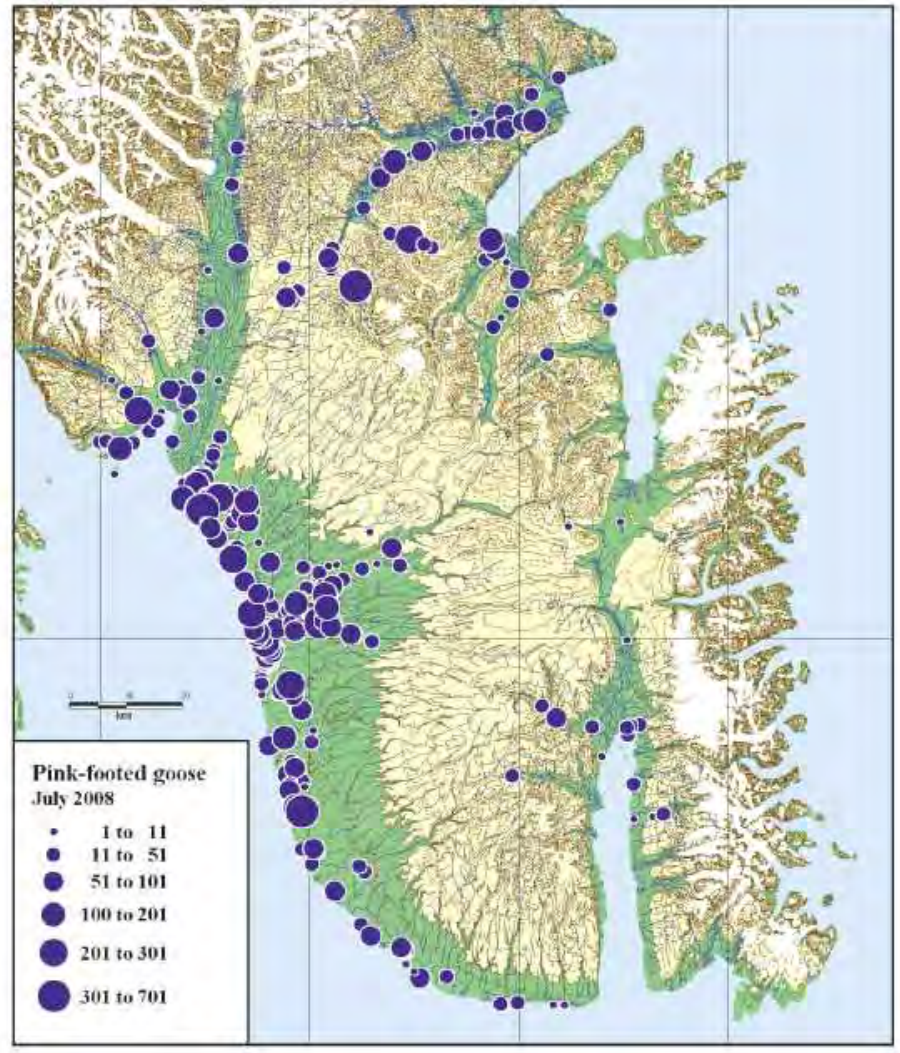

Figure 2. Distribution of flocks of Pinkfooted geese in Jameson Land recorded during aerial surveys on 17 and 18 July 2008. Flock sizes are indicated by the size of the signature. In total 384 flocks with a total of 19,068 birds were recorded (corrected for birds recorded more than once).

Udbredelsen af flokke af Kortnobbede Gaes $i$ Jameson Land optalt fra luften $d$. 17. og 18. juli 2008. Størrelsen af flokken er angivet ud fra signaturens størrelse. Der blev $i$ alt optalt 384 flokke med $i$ alt 19.068 gas. Antallet er korrigeret for gentagelser.

Table 2. Moulting Pink-footed Geese and family geese (separated in adults and young) counted in the four study areas either from the air or from the ground.

Faeldende Kortncebbede Gas og familier af arten optalt $i$ de fire undersøgelsesområder fra henholdsvis luften og på jorden.

\begin{tabular}{lccccc}
\hline Study area & Aerial survey & \multicolumn{4}{c}{ Ground count } \\
\cline { 2 - 5 } & Moulting & Moulting & Family & Adults & Young \\
\hline Gurreholm & 3971 & 2752 & 834 & 442 & 392 \\
Tyskit Nunaat & 969 & 1090 & 83 & 57 & 26 \\
Draba Sibirica Elv & 2483 & 2756 & 770 & 338 & 432 \\
Ørsted Dal & 408 & 166 & 54 & 27 & 27 \\
\hline
\end{tabular}

Table 3. Barnacle Goose moulting and family birds (separated in adults and young) counted in the four study areas either from the air or from the ground.

Faeldende Bramgaes og familier af arten optalt $i$ de fire undersøgelsesområder fra henholdsvis luften og på jorden.

\begin{tabular}{lccccc}
\hline Study area & Aerial survey & \multicolumn{4}{c}{ Ground count } \\
\cline { 3 - 5 } & Moulting & Moulting & Family total & Adults & Young \\
\hline Gurreholm & 284 & 167 & 8 & 6 & 2 \\
Tyskit Nunaat & 269 & 201 & 0 & 0 & 0 \\
Draba Sibirica Elv & 1122 & 240 & 37 & 14 & 23 \\
Ørsted Dal & 542 & 696 & 123 & 82 & 41 \\
\hline
\end{tabular}


Figure 3. Distribution of flocks of Barnacle geese in Jameson Land recorded during aerial surveys on 17 and 18 July 2008. Flock sizes are indicated by the size of the signature. In total 431 flocks with a total of 16,630 birds were recorded (corrected for birds recorded more than once).

Udbredelsen af flokke af Bramgas $i$ Jameson Land optalt fra luften d. 17. og 18. juli 2008. Størrelsen af flokken er angivet ud fra signaturens størrelse. Der blev $i$ alt optalt 431 flokke med $i$ alt 16.630 gaes. Antallet er korrigeret for gentagelser.

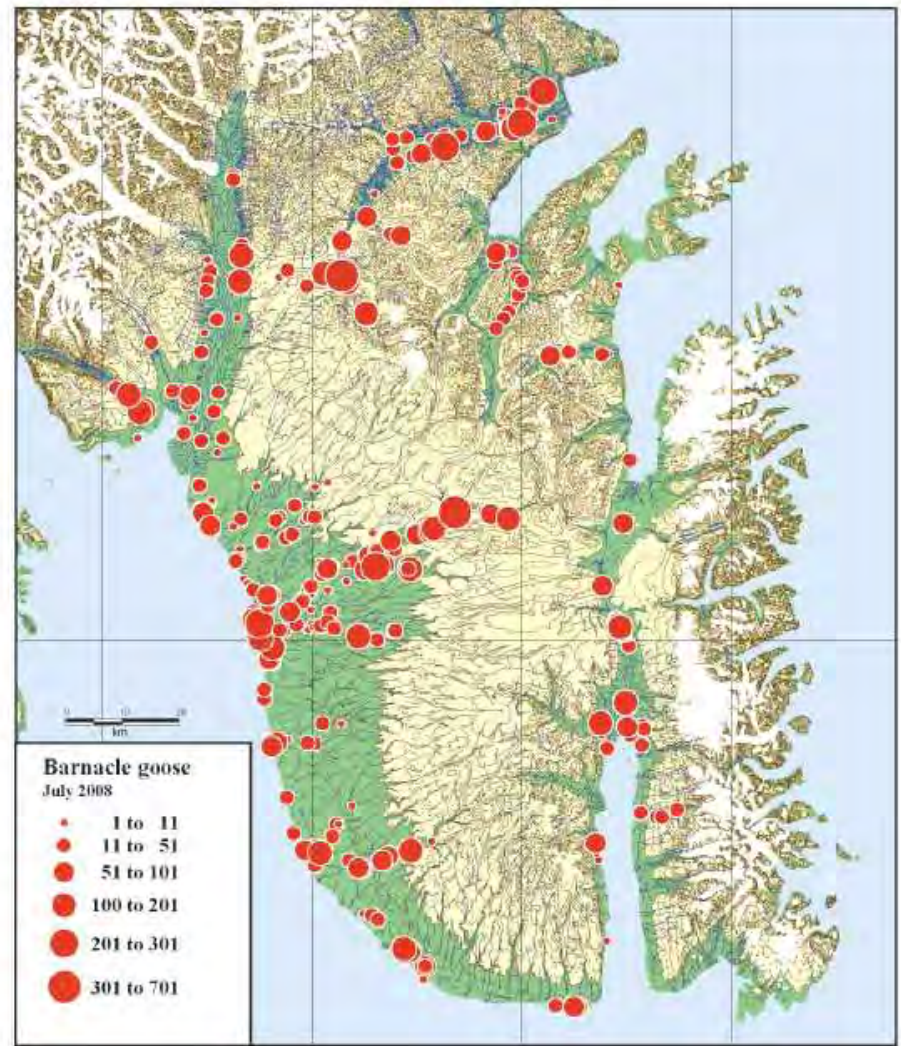

Table 4. The number of breeding bird pairs and species (geese excluded) in the four study areas in Jameson Land. Breeding birds are successfully pairs only. Species are mainly waders, ducks, divers and skuas.

Antallet af ynglende par og arter (gaes indgår ikke) $i$ de fire undersøgelsesområder $i$ Jameson Land. Ynglefuglene omfatter kun succesfulde par. Arterne omfatter primart vadefugle, cender, lommer og kjover.

\begin{tabular}{lrrrr}
\hline Study area & Gurreholm & Tyskit Nunaat & Draba Sibirica Elv & Ørsted Dal \\
\hline Area $\left(\mathrm{km}^{2}\right)$ & 68.9 & 48.6 & 65.6 & 53.2 \\
Breeding bird pairs & 64 & 22 & 20 & 30 \\
Breeding birds species & 11 & 10 & 9 & 5 \\
\hline
\end{tabular}

\section{Discussion}

\section{Methods, aerial goose census}

We believe that the results from the present survey and the surveys performed in the 1980s are comparable because the methodology used was as identical as possible regarding aircraft, personnel and census route. In 1988 and 1989 photographic verification was added to the aerial surveys (Mosbech et al. 1989, Mosbech \& Glahder 1990). The numbers of observed Pink-footed Geese and Barnacle Geese were adjusted according to photographed flocks to give true numbers. In general, flocks below 75 geese were overestimated by $13.6 \%$ while flocks above 75 geese were underestimated by $3.2 \%$. In 2008, no photographs were taken, but if we use the above results on our flocks, the total count of Pink-footed Geese and Barnacle Geese should be reduced by $2 \%$ and $3 \%$, respectively. Due to these small differences we have kept the observed numbers in this paper. 


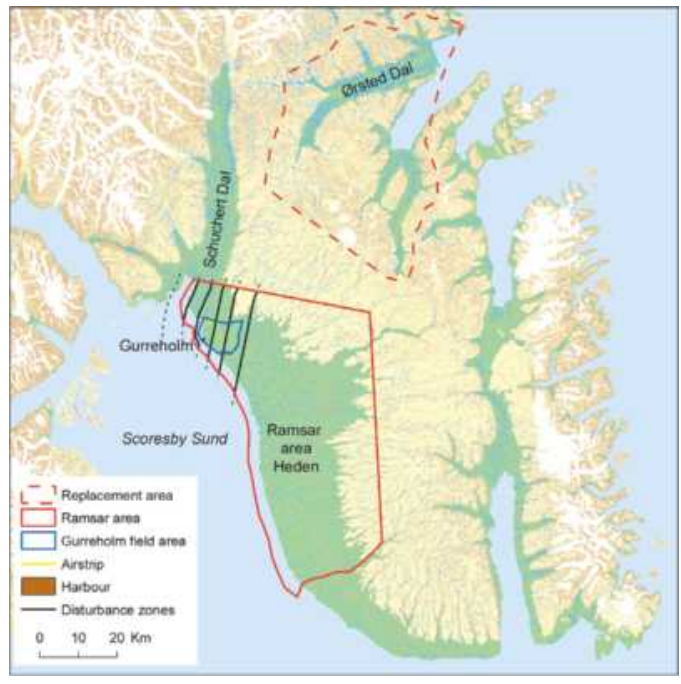

Figure 4. Map of Jameson Land with the Ramsar site Heden, Gurreholm and the air strip and the port. The three disturbance zones of 1.5, 5 and $10 \mathrm{~km}$ from the mining works are shown in black lines. The proposed replacement area around the Ørsted Dal is shown.

Kort over Jameson Land med Ramsar området Heden, Gurreholm, landingsbane og havn. De tre forstyrrelseszoner med afstande på 1,5,5 og $10 \mathrm{~km}$ fra mineanlaggene er vist med sorte linjer. Det foreslåede erstatningsområde ved Ørsted Dalen er vist.

\section{Methods, ground surveys}

Ground surveys in the four study areas were performed identically with special focus on moulting and breeding geese. The aim was to obtain full coverage of moulting geese and family flocks inside the study areas. This was done by daily walking trips and observations from vantage points covering all major water bodies and wetland areas. Moulting geese counted from the air and the ground in the four study areas differed, but not systematically. Pink-footed Geese counted from the ground differed from the aerial count in most cases between $70 \%$ and $113 \%$, yet with only $41 \%$ found in Ørsted Dal. In Barnacle geese the differences varied in most cases between $60 \%$ and $128 \%$ with only $21 \%$ found in the Draba Sibirica Elv area. The large difference in Ørsted Dal could be due both to the different census periods and to the possibility of the geese to move along the main river and out of the study area. In Draba Sibirica Elv many of the moulting Barnacle Geese counted from the air were observed along the coastline and these flocks could have moved out of the study area when the ground team arrived about one week later. The most marked difference between the two methods was that the ground counts observed a total of 1741 Pink-footed family geese and 168 Barnacle Goose family birds, while only 2 Barnacle Goose family birds were observed in the study areas from the air. Family birds are not observed from the air either because they blend into the moulting geese or they are invisible while feeding on the tundra or in marsh areas.

The ground observations of other birds than geese from the four study areas were focusing on breeding birds. In July, birds are either incubating or attending young birds, so at this time of the breeding season we will observe only successfully breeding birds. Failed breeders constitute a major part of the breeding population and in July, these birds have gathered in flocks. Therefore, numbers of breeding birds represent minimum. A more comprehensive method of counting breeding birds is given by Meltofte (2001).

\section{Goose populations in Jameson Land}

During 1983-1989 the moulting geese from the two populations were censused from the air in 1983, 1984, 1987-1989 (Mosbech \& Glahder 1990). On average 6,071 $(\mathrm{SD}=634, \mathrm{n}=5)$ Barnacle Geese and 6,243 ( $\mathrm{SD}=1,012, \mathrm{n}=5)$ Pink-footed Geese were counted. The global flyway populations of the two species were in 1990 estimated at 35,000 Barnacle Geese and 190,000 Pink-footed Geese and in 2007 and 2008 to 70,500 Barnacle Geese and 290,000 Pink-footed Geese (Table 1, Mitchell 2008, Mitchell \& Walsh 2008). It appears from Table 1 that the global populations during the 20 years period have increased 1.5-2 times while the moulting geese from the two populations in Jameson Land have tripled their numbers. The proportion of Barnacle Geese in Jameson Land of the total population has increased over the period from $17 \%$ to $24 \%$ and for Pink-footed Geese from 3\% to 7\%. The increase of the two species in Jameson Land over the 20 years period is not evenly distributed. In the Ørsted Dal replacement area proposal (Figure 4) both species have more or less doubled their number (Barnacle Goose from 2377 (average 1983-1989) to 4106, and Pink-footed Goose from 960 to 1952). In the Gurreholm area, on the other hand, the number of Barnacle Geese has decreased to nearly the half (from 430 to 284), while Pink-footed Geese have 
increased their number six fold (from an average of 634 to 3971). In the Draba Sibirica Elv area numbers of the two species have not changed much in the 20 year period (Barnacle Goose 1980s-average of 1114 compared to 1122 in 2008, and Pink-footed Goose numbers have increased slightly from 2030 to 2483). Especially in the Gurreholm area the expanding Pink-footed Goose population has been able to find unexploited habitats. Consequently, about $25 \%$ of the entire Jameson Land population of moulting Pink-footed Geese are today using the Gurreholm area as a moulting ground.

\section{Breeding geese in Jameson Land}

In the four ground study areas we have counted 1741 family group individuals of Pink-footed Geese and 168 family group individuals of Barnacle Goose. This gives about 370 successfully breeding pairs of Pink-footed Geese and 30-45 pairs of Barnacle Geese in the four study areas. During the 1980s the total Jameson Land breeding population of the Pink-footed Goose was estimated at 300-500 pairs in 1982-1984 (Madsen et al. 1985) and 600 in 1988 (Mosbech et al. 1989). The breeding population of the Barnacle Goose was in 1982-1984 estimated at 300-400 pairs. In the Ørsted Dal the breeding population was, on the basis of juveniles, estimated at about 60 pairs in 1963 and 1974 (Hall \& Waddingham 1966; Ferns \& Mudge 1976) and 201 nest in 9 colonies in June 1984 (Cabot et al. 1984).

\section{Birds in the Gurreholm area}

The Gurreholm area is very rich in bird species and individuals compared to the other three studied areas. The number of breeding and moulting Pink-footed Geese (more than 800 individuals in families and c. 4000 moulting birds) as well as other breeding birds (11 species with 64 successfully pairs) is high (Table 2 and 4). The area is not very important for Barnacle Geese where the highest number of breeding birds (123 individuals) was observed in Ørsted Dal and the highest number of moulting birds (c. 1100) was counted in the Draba Sibirica Elv area. The reason for this relative high biodiversity is the high number of different habitats such as many larger and smaller lakes and rivers, fens and salt marshes. This mosaic of wet areas is dominating over the dryer dwarf scrub heath. The Tyskit Nunaat area is dominated by dwarf scrub heath with only few lakes, rivers and fens, while the Ørsted Dal and Draba Sibirica
Elv areas are intermediate between the two areas described above.

\section{Possible effects of mining activities}

The possible effects of the mining activities on geese and other bird species in the Gurreholm area were evaluated in relation to three disturbance scenarios, expressed by the distance at which birds are predicted to be displaced. The size of these three zones of 1.5, 5 and $10 \mathrm{~km}$ (Figure 4) are based on knowledge from reactions of moulting geese to helicopter disturbances (Mosbech et al. 1989, Mosbech \& Glahder 1991) and breeding geese to airstrips and walking persons (de Korte 1988, Mosbech et al. 1989, Mosbech \& Glahder 1990). When a large helicopter approached moulting Pink-footed Geese they stayed alert at a distance of about 10 $\mathrm{km}$ from the plane and fled to a lake or river at distances of 7-8 km. A smaller helicopter caused the two latter reactions at distances of 4-6 km. When geese, still able to fly, are searching for suitable moulting sites they probably will avoid moulting habitats that are inside the $10 \mathrm{~km}$ disturbance zone. This is based on observations of Pink-footed Geese that avoided a valley in Jameson Land in late June after passage of large helicopters at distances of about $5 \mathrm{~km}$. No geese moulted in the valley that year. Breeding geese are more tolerant to disturbances and observations in Jameson land indicate little or no effects at distances of 1-2 km from the source. A similar disturbance effect was found in breeding Pink-footed Geese in Iceland (Sigurdsson 1974) and in Svalbard, Pink-footed Goose families showed an escape response at a distance of almost $2 \mathrm{~km}$ from approaching humans (Madsen et al. 2009). According to these observations we have chosen a disturbance zone of $1.5 \mathrm{~km}$ to breeding geese and other breeding birds. A worst case scenario is represented by the $10 \mathrm{~km}$ disturbance zone inside which we expect that no geese will start moulting (Figure 4). The more moderate scenario anticipates the geese to initiate their moult in areas situated more than $5 \mathrm{~km}$ from the disturbances, but inside the $5 \mathrm{~km}$ zone no geese will moult. Breeding geese and other breeding birds are expected to avoid the area inside the $1.5 \mathrm{~km}$ disturbance zone.

Inside the disturbance zone of $10 \mathrm{~km}$ about 4900 moulting Pink-footed Geese and 530 moulting Barnacle Geese were observed in 2008, while the disturbance zone of $5 \mathrm{~km}$ held c. 3900 moulting Pink-footed Geese and 400 moulting Barnacle Geese. Inside the $1.5 \mathrm{~km}$ disturbance zone a minimum of 150 Pink-footed Geese in family flocks 
(equal to c. 30 successful pairs) and a minimum of 8 breeding pairs of other breeding birds were located. It is likely that all lakes used by foraging non-breeding Sabine's Gulls will be affected by the constructions.

\section{The proposed replacement area in Ørsted Dal}

In Jameson Land, we found the Ørsted Dal area to be the only relevant potential replacement area. The area had to be extended to that shown on Figure 4, because the Ørsted Dal study area, similar in size to the Gurreholm study area, held too few moulting and breeding Pink-footed Geese. Also, it was doubtful if the area was sufficient to replace the diversity of other breeding species. On the other hand, Barnacle Geese are fully replaced. This extended Ørsted Dal area held c. 3000 moulting Pinkfooted Geese or about $60-80 \%$ of the $3900-4900$ geese potentially lost inside the two disturbance zones in the Gurreholm area. In return, the extended Ørsted Dal area supports c. 4700 moulting Barnacle Geese giving protection under the Ramsar Convention to an extra 7\% of the Barnacle Goose flyway population. This is of importance because the population is still relatively small despite its current rapid growth. With our current knowledge, it is difficult to judge if the replacement area can fully compensate the loss of breeding Pink-footed Geese and other breeding birds. The south-eastern valleys in the area (Figure 4) are suitable only to moulting geese and not to most breeding birds because of snow and ice coverage until late June.

Because of the uncertainties to assess the impact of the mining activities on the moulting and breeding birds in the Gurreholm area of the Ramsar site we suggest a monitoring program be initiated at mine start. If the proposed Ørsted Dal replacement area can not compensate for the loss of moulting and breeding birds in the Gurreholm area, yet another replacement area should be delimited elsewhere along the East Greenland coast.

\section{Acknowledgements}

We wish to thank the following persons from the department of Arctic Environment, National Environmental Research Institute, Aarhus University, who contributed with data handling, comments and preparations of figures: Morten Bjerrum, Jannik Hansen, Kasper Johansen, Anders Mosbech and Mikkel Tamstorf. In the field we had excellent help from Cornelia Jaspers, Kent Olsen, Leif Petersen and Alyn Walsh. The Bureau of Minerals and Pe- troleum, Greenland Self-Government/Naalakkersuisut is thanked for financial support.

\section{References}

Boertmann, D. 1991. Distribution and numbers of moulting non-breeding Geese in Northeast Greenland. Dansk Orn. Foren. Tidsskr. 85: 77-88.

Boertmann, D. 2007. Grønlands Rødliste 2007. Grønlands Hjemmestyre, Danmarks Miljøundersøgelser, Aarhus Universitet. Pp. 152.

Cabot, D., Nairn, R., Newton, S. \& Viney, M. 1984. Biological Expedition to Jameson Land, Greenland 1984. Expedition Report. Barnacle Books, Dublin.

Cessford, F. 2007. Environmental and social assessment of the Malmbjerg project. Vol. 1 - Main report. SRK Consulting, British Columbia, Canada. Pp. 192.

de Korte, J. 1988. Observations of birds and mammals from the Hurry Inlet Area, Scoresby Sund, 1988. Circumpolar Journal 3(4): 1-5.

Egevang, C. \& Boertmann, D. 2001. The Greenland Ramsar sites, a status report. National Environmental Research Institute, Denmark, NERI Technical Report No. 346, 95 pp.

Ferns, P. N. \& Mudge, G. P. 1976. Abundance and breeding success of birds in Ørsted Dal, East Greenland, 1974. Dansk Orn. Foren. Tidskr. 70: 21-33.

Glahder, C.M., Boertmann, D., Madsen, J., \& Bjerrum, M. 2008. Preliminary assessment of the impact of Quadra Mining on birdlife in the Heden Ramsar site and proposal for a replacement area. National Environmental Research Institute, Aarhus University, report to the Bureau of Minerals and Petroleum, Greenland Home Rule. 36 pp.

Glahder, C.M., Boertmann, D., Madsen, J., Tamstorf, M., Johansen, K., Hansen, J., Walsh, A., Jaspers, C. \& Bjerrum, M. 2010. Biological baseline study in the Ramsar site "Heden" and the entire Jameson Land, East Greenland. National Environmental Research Institute, Aarhus University. NERI Technical Report no. 769, 86 pp.

Greenland Home Rule 1990. International wetlands in Greenland. Ramsar-sites. Greenland Home Rule, Department of Physical Planning and Nature Management, Nuuk, Greenland.

Hall, A.B. \& Waddingham, R.N. 1966. The breeding birds of Ørsted Dal, East Greenland, 1963. Dansk Orn. Foren. Tidskr. 60: 186-197.

Laursen, K., Frikke, J. \& Kahlerth, J. 2008. Accuracy of 'total counts' of waterbirds from aircraft in coastal waters. Wildlife Biology. 14: 165-175.

Madsen, J., Tombre, I. \& Eide, N.E. 2009. Effects of disturbance on geese in Svalbard. implications for regulating increasing tourism. Polar Research 28(3): 376-389.

Madsen, J., Mortensen, C.E. \& Boertmann, D.M. 1985. Gassene $i$ Jameson Land, resultater af undersøgelser 1982-1984. Grønlands Fiskeri- og Miljøundersøgelser, Zoologisk Museum, København.

Meltofte, H. 2001. Wader Population Censuses in the Arctic. Getting the Timing Right. Arctic 54: 367-376.

Mitchell, C. 2008. The Icelandic-breeding Goose Census 2007. Goose News no. 7: 13-14. Wildfowl \& Wetlands Trust, Slimbridge, UK.

Mitchell, C. \& Walsh, A. 2008. The rise and rise of Green- 
land Barnacle Geese. Goose News no. 7: 5. Wildfowl \& Wetlands Trust, Slimbridge, UK.

Mortensen, C.E., Glahder, C. \& Mosbech, A. 1988. Gåseundersøgelser $i$ Jameson Land 1987. Grønlands Miljøundersøgelser.

Mosbech, A. \& Glahder, C. 1990. Gåseundersøgelser i Jameson Land 1989 og resultater af moniteringen af gas $i$ Jameson Land fra 1983 til 1989. Grønlands Miljøundersøgelser, $50 \mathrm{pp}$.

Mosbech, A. \& Glahder, C. 1991. Assessment of the impact of helicopter disturbance on moulting Pink-footed geese Anser brachyrhynchus and Barnacle geese Branta leucopsis in Jameson Land, Greenland. Ardea 79: 233-238.

Mosbech, A., Clausen, P., Glahder, C. \& Witting, L. 1989. Gassene $i$ Jameson Land 1988. Grønlands Miljøundersøgelser, $98 \mathrm{pp}$.

Quadra Mining Ltd. 2008. Malmbjerg Project, Feasibility Study, Vol. 5, Airstrip, Port and Access Road. Pp. 39.

Sigurdsson, J. B. 1974. Studies on breeding biology of Pinkfooted geese (Anser brachyrhynchus). Skyrsla um rannsóknir I Thjórsarverum 1972. Reykjavik, Island.

\section{Sammenfatning}

Ramsarområdet Heden i Østgrønland $\left(71^{\circ} 00^{\prime} \mathrm{N}\right.$; $\left.24^{\circ} 00^{\prime} \mathrm{W}\right)$ blev i 1988 udpeget for at beskytte internationalt vigtige populationer af fældende Kortnæbbede Gæs og Bramgæs. På det tidspunkt udgjorde antallet i området henholdsvis $2 \%$ og $7 \%$ af de to populationer. Et mineselskab fik i 2008 tildelt en udnyttelsestilladelse for Malmbjerget der ligger ca. $75 \mathrm{~km}$ nord for Ramsarområdet. Det er mineselskabets plan at udnytte en stor molybdænforekomst og bygge infrastruktur i det nordvestlige hjørne af Heden, kaldet Gurreholm (Figur 1). Byggerierne omfatter en havn, en grusvej og en 2 $\mathrm{km}$ lang landingsbane. Mineprojektet er af "højeste nationale interesse" for Grønlands Selvstyre. Ramsarkonventionens secretariat har accepteret, at mineprojektet kan fortsætte, hvis påvirkningen fra mineaktiviteterne moniteres og der findes et passende erstatningsområde inden minestart. Danmarks Miljøundersøgelser, Aarhus Universitet, udførte i juli 2008 en række biologiske undersøgelser i Ramsarområdet og i det øvrige Jameson Land. Jameson Land er et lavlandsområde sammenlignet med den meget bjergrige Grønlandske østkyst. Jameson Land er mod vest afgrænset af Verdens største fjordsystem Scoresby Sund og mod nord og øst af høje bjerge og det åbne hav. Mod vest er området dækket af tundra der er præget af relativt mange vådområder. Mod øst rejser landet sig gradvist og går over i lavere bjerge. Området er gennemskåret af adskillige store elve med relativt frodige dale. Optællingen fra fly dækkede de fleste lavlandsområder, mens undersøgelserne på jorden omfattede tre områder i Ramsarområdet og et udenfor.
Undersøgelserne blev udført i perioden 16. juli til 2. august 2008. Optællingen fra fly blev foretaget d. 17. og 18. juli og den var sammenlignelig med undersøgelserne i samme område fra 1987-1989, idet fly, pilot, observatør og ruter var identiske. Ruterne blev fløjet som "total counts". Studieområderne blev dækket af ruter på i alt $50-100 \mathrm{~km}$, der udgik som radier fra lejrene og der blev specielt fokuseret på søer og elve. Fra luften blev der i alt optalt 19.068 fældende Kortnæbbede Gæs og 16.603 Bramgæs (Tabel 1, Figurerne 2 \& 3). I hvert af de fire undersøgelsesområder blev der optalt fældende gæs og familieflokke både fra luften og fra jorden (Tabellerne $2 \& 3$ ). Desuden blev antallet af succesfulde ynglefugle af andre arter registreret $\mathrm{i}$ de fire områder (Tabel 4). Disse ynglefugle omfattede vadefugle, ænder, kjover og andre arter som f.eks. Sabinemåge. Antallet af fældende gæs talt fra luften og fra jorden varierede, men ikke systematiskt. Den mest markante forskel på de to optællingsmetoder var, at der fra jorden blev observeret $\mathrm{i}$ alt 1.741 Kortnæbbede Gæs i familier og 168 Bramgæs, men der fra luften stort set ikke blev set gæs i familier. Grunden til, at der ikke bliver set familiegæs fra luften skyldes dels, at disse forsvinder i de tætte flokke af fældegæs og dels, at de ofte opholder sig på tundraen eller i kærområder, hvor de er særdeles vanskelige at opdage. I perioden 1983-1989 blev der i gennemsnit observeret ca. 6.000 fældegæs af hver af de to arter. I perioden fra 1990 til 2007/2008 er antallet af de to flyway populationer forøget med 1,5-2 gange, mens de fældende gæs fra de to populationer i samme periode har forøget deres antal i Jameson Land med tre gange (Tabel 1); i Gurreholm området er antallet af Kortnæbbede Gæs øget seks gange. Det betyder, at ca. 25\% af de fældende Kortnæbbede Gæs i Jameson Land i dag opholder sig i Gurreholm området. Mineaktiviteternes mulige påvirkninger af gæs og andre fugle i Gurreholm området blev vurderet ud fra tre forstyrrelsesscenarier, udtrykt som den afstand til kilden hvor fuglene vil blive bortjaget. Størrelsen af de tre zoner på 1,5, 5 og $10 \mathrm{~km}$ (Figur 4) er baseret på forstyrrelsesreaktioner som fældende og ynglende gæs har udvist i Jameson Land. Indenfor $10 \mathrm{~km}$ zonen blev der i 2008 observeret ca. 4.900 fældende Kortnæbbede Gæs og 530 fældende Bramgæs, mens der indenfor $5 \mathrm{~km}$ zonen blev observeret ca. 3.900 fældende Kortnæbbede Gæs og 400 fældende Bramgæs. Indenfor 1,5 km zonen blev der set ca. 30 succesfulde ynglepar af Kortnæbbet Gås og her ligger også de søer, hvor der blev set flokke af ikke-ynglende Sabinemåger. Ørsted Dal området var det eneste relevante po- 
tentielle erstatningsområde i Jameson Land (Figur 4). I dette område blev der set ca. 3.000 fældende Kortnæbbede Gæs, hvilket udgør 60-80 \% af de gæs der potentielt bortjages fra de to forstyrrelseszoner. På den anden side blev der observeret ca. 4.700 fældende Bramgæs, således at yderligere
$7 \%$ flere af denne population vil blive beskyttet af Ramsarkonventionen. Det er foreslået, at der efter minestart foretages en monitering af konsekvenserne og at der i nærmeste fremtid undersøges andre mulige erstatningsområder. 